\title{
Grænser for ytringsfrihed
}

\author{
AF EJVIND HANSEN
}

\section{Indledning}

Denne artikel sætter spørgsmålstegn ved ytringsfriheden. Grundlæggende set vil jeg argumentere for, at ytringsfriheden kun har en eksistensberettigelse, hvis vi kan diskutere den uden at skulle være bange for at miste den. Jeg vil argumentere for, at ytringsfriheden grundlæggende set må være begrænset, og at det derfor altid er påtrængende at diskutere, om de givne grænser er de mest oplagte i enhver given samfundsmæssig situation.

Konkret vises dette ved at artikulere, hvorledes ytringsfriheden er et barn af Oplysningstiden, hvor demokratisk politik tænkes som en fortløbende, rationel legitimeringsproces. Denne forståelse af politikken fungerede fint i en samfundsformation, der klart adskiller det politiske fra det økonomiske. Med fremvæksten af globalt orienterede, kommunikative medier er det imidlertid spørgsmålet, om denne adskillelse kan opretholdes. Derfor er det påtrængende at få nyartikuleret grundlaget for og formen på den gældende ytringsfrihed.

\section{Den paradoksale ytringsfrihed}

I Danmark bryster vi os ofte af en demokratisk og sekulær debatkultur. En demokratisk og sekulær debatkultur er kendetegnet ved, at alle kan komme til orde (det demokratiske), og at intet i princippet er helligt (det sekulære, frigjortheden fra religiøse dogmer). Disse to sider ved debatkulturen findes legemliggjort i den hævdvundne ytringsfrihed, der bl.a. er artikuleret i Grundloven (\$77) og Den Europæiske Menneskerettighedskonvention (artikel 10). 
Ytringsfriheden er en kernepille ved den demokratiske struktur. Netop fordi den er så dybt indlejret i den demokratiske struktur, er det tæt på at være politisk selvmord at gøre sig til talsmand for at begrænse den yderligere. I udgangspunktet er ytringsfriheden og dens grænser derfor ikke selv til debat. Ganske vist henvises der ofte til ytringsfriheden i diskussioner, men så starter det som regel med, at man beskylder de andre for ikke at respektere ytringsfriheden. Vi så det f.eks. under Muhammed-kriserne, da den danske statsminister nægtede at følge en opfordring fra 11 ambassadører om at forholde sig til nogle karikatur-tegninger af Muhammed, som var blevet bragt i Jyllands-Posten. Argumentet var her netop, at det ville være en krænkelse af ytringsfriheden (se bl.a. TV2 Nyhederne 2005). Ambassadørerne på deres side opfattede det imidlertid ikke som et forsøg på at lukke ned for ytringsfriheden. Man ønskede derimod, at statsministeren skulle markere, hvorvidt det danske samfund sigter mod kulturel integration eller krænkelse af islam (Politiken 2006). Man ønskede altså ikke at hindre nogen (f.eks. Jyllands-Posten) i at sige noget, men at få nogle oplysninger om, hvad der er den danske regerings langsigtede politik.

Jeg vil i denne artikel ikke forholde mig til, hvad der var den rette handlemåde i den konkrete situation. Jeg har primært taget eksemplet frem, fordi det paradigmatisk illustrerer et karakteristisk forhold ved den rolle, ytringsfriheden spiller i vores debatkultur: I det øjeblik man kan beskylde de andre for at ville begrænse ytringsfriheden, behøver man ikke længere tage deres synspunkter alvorligt. I nogle sammenhænge blev der draget en parallel mellem, om man tilhørte en oplyst, sekulær kultur, hvor man kunne diskutere alt, eller om man tilhørte en formørket, religiøs kultur, der forhindrer den frie tanke (Juhl 2010). Det påfaldende i denne situation er, at hvor den ene side (de oplyste demokrater) i denne diskussion klandrer den anden (de formørkede fundamentalister) for at stille for mange ting uden for diskussionens rækkevidde, så holder den samme side (altså demokraterne) selv ét af sine mest fundamentale dogmer uden for diskussionens rækkevidde. Ytringsfrihedens forkæmpere har meget svært ved at diskutere ytringsfriheden - det er et paradoks.

At man kan finde paradokser i vores omgang med det politiske, bør ikke overraske. Selve den demokratiske ide er allerede 
paradoksal. Det kan man se ved at spørge sig selv, hvordan man kan udvikle et ikke-demokratisk samfund til et demokratisk samfund? Her bliver det hurtigt klart, at demokrati ikke kan indføres demokratisk. Demokratiet er nødt til at blive indført uden at spørge borgerne til råds. Hvis man spørger alle, om demokratiet skal indføres, har man allerede indført det. Nogle (få) er nødt til at træffe beslutningen om, at alle skal spørges.

Lidt på samme måde vil mange demokrater også blive lidt usikre, hvis man spørger dem, om det kan accepteres, at borgerne vælger at afskaffe demokratiet? I december 1991 blev første valgrunde i Algeriet vundet af Den Islamiske Frelserfront, der havde det som erklæret mål at indføre en ikke-demokratisk, islamisk stat. Valget blev siden annulleret ved et militærkup - og demokratiet overlevede således ved hjælp af voldelig intervention. I Algeriet kunne man altså ikke vælge at frasige sig sine valgmuligheder.

Den paradoksale struktur ved demokratiet og ytringsfriheden er ikke nogen ny opdagelse. Giorgio Agamben har bl.a. analyseret den i hovedværket Homo sacer: sovereign power and bare life, der oprindeligt udkom på italiensk i 1995. Her pointerer han, at al demokratisk politik nødvendigvis må etableres gennem en oprindelig ikke-demokratisk beslutning: Politiske beslutninger må etableres i en lovgivning, der regulerer vore handlinger. Og man kan kun tænke sig en regelmæssig regulering, i det omfang man kan forstå, hvad der ville udgøre et brud med reglen. Loven kan derfor kun etableres ved at ekskludere en række handlinger som værende ureglementerede (Agamben 1998, s. 15-19). Loven om den demokratiske struktur kan tilsvarende derfor kun realiseres ved at stadfæste, at der er visse strukturer, som ikke er acceptable. Vi kan med andre ord kun frisætte borgeren til det frie valg, hvis vi på forhånd bestemmer, at der er visse valg, borgeren ikke har lov at foretage.

Agamben bruger ikke denne paradoksale struktur på det demokratiske som en anledning til at forkaste demokratiet. Han tager her udgangspunkt i Jacques Derridas pointe om, at enhver kultur og politisk struktur nødvendigvis vil have en paradoksal struktur (se bl.a. Derrida 1994; 1996). Agamben bruger det imidlertid alligevel som anledning til at levere en kritisk bredside mod den nuværende politiske struktur i de vestlige lande. Problemet 
er nemlig, at vi i dag tenderer til at benægte, at der findes et ekskluderet "udenfor" i vores politiske struktur. Og den skråsikkerhed, som følger af dén overbevisning, vil i sin yderste konsekvens føre til overgreb som udryddelseslejrene i det nazistiske Tyskland (Agamben 1998, s. 20).

Oversat til debatten om ytringsfrihed kan man sige, at i takt med at ytringsfriheden stigmatiseres som en ret og en frihed, der ikke kan diskuteres, risikerer den at blive decideret undertrykkende. Vi kan måske ligefrem miste evnen til at kommunikere frugtbart med kulturer, der adskiller sig fra vores egen - hvilket Muhammed-krisen måske var et første eksempel på. Lige meget hvilket parti man tager i den krise, fornærmer man nok ikke nogen ved at konkludere, at der var dårlig kommunikation og dialog mellem de involverede parter.

\section{Den begrænsede ytringsfrihed}

I en ophedet politisk situation, der næppe i sig selv vil overleve den langsigtede politiske hukommelse, er den dengang siddende kulturminister, Per Stig Møller, citeret for at sige, at det er "overhovedet ikke en debat værd at indskrænke ytringsfriheden" (Vangkilde 2011). I forbindelse med Politikens undskyldning for sin genoptrykning af Muhammed-tegningerne i 2008 blev Tøger Seidenfaden fordømt ud fra lignende synspunkter af fremtrædende toppolitikere fra hele det politiske spektrum, sekunderet af flere fremtrædende mediefolk (Clemmensen 2010).

Det er et godt billede af en generel tilgang til ytringsfriheden. Når så mange er afvisende over for at diskutere ytringsfriheden, hænger det givetvis sammen med, at man er bange for at begrænse den. Man har en ide om, at hvis vi begrænser ytringsfriheden, er vi på en glidebane mod afskaffelsen af ytringsfriheden og dermed demokratiet. Men ville det overhovedet være attraktivt at have en ubegrænset ytringsfrihed? Jeg vil i denne artikel vise, at det ville det ikke.

Agambens pointe om, at love og rettigheder altid kun kan fungere gennem eksklusioner, burde allerede gøre det klart, at helt så simpelt kan det ikke forholde sig - ytringsfriheden er nødt til at være begrænsende. Man kan kun indføre en ret (ytringsfriheden) ved at forhindre visse former for handling. Helt oplagt kan man 
naturligvis kun have ytringsfrihed, for så vidt at man udelukker muligheden for at lave regler, der forhindrer ytringer. Men kan man have en absolut ytringsfrihed, hvor det er tilladt at sige alt ville det være attraktivt?

Hvis man bliver meget filosofisk, kan man naturligvis godt tænke sig et samfund, hvor alle må sige, hvad de vil, men det er spørgsmålet, om det ville give mening at kalde dette ytringsfrihed? Oluf Jørgensen har således vist, at ytrings (og informations-)friheden er snævert bundet op omkring forestillingen om personlig integritet (Jørgensen 2011, s. 22-23). Pointen er her, at lige så vel som ytringer kan bruges til at manifestere og befæste individuel integritet, kan ytringer også bruges til at nedbryde den samme integritet, hvis ytringerne ikke respekterer nogle grænser mellem de private og offentlige sfærer. Mere abstrakt kan man sige, at for at det skal give mening at tale om en ytringsfrihed, er det ikke nok at definere den negativt (som en frihed fra ydre begrænsninger). En udelukkende negativt defineret ytringsfrihed ville kunne udarte til et ytringstyranni: Ved at underminere grænserne mellem det private og offentlige ville den tilgrundliggende individualitet også blive undermineret (gennem tabet af personlig integritet), og det offentlige rum for ytringer ville udarte til irrelevant råben uden (kohærent) relation til personlige holdninger, bekymringer og engagement.

For at ytringsfriheden skal give mening, er det derfor afgørende, at den begrænses på forskellige måder ud fra nogle ideer om, hvad friheden skal bruges til (et positivt frihedsbegreb). Hvis man kigger på vores konkrete ytringsfrihed, bliver det også meget klart, at ophavsmændene til den nuværende rettighed ikke har ment, at en ubegrænset ytringsfrihed ville være attraktiv. Vores egen grundlov siger det således:

\section{"Enhver er berettiget til på tryk, i skrift og tale at offentliggøre}

sine tanker, dog under ansvar for domstolene." (Danmarks Riges

Grundlov, §77)

Grundloven åbner således for, at ytringsfriheden kan begrænses gennem lovgivning. I Danmark realiseres en sådan begrænsning bl.a. i "racismeparagraffen" i Straffeloven: 
"Den, der offentligt eller med forsæt til udbredelse i en videre kreds fremsætter udtalelse eller anden meddelelse, ved hvilken en gruppe af personer trues, forhånes eller nedværdiges på grund af sin race, hudfarve, nationale eller etniske oprindelse, tro eller seksuelle orientering, straffes med bøde eller fængsel indtil 2 år." (Straffeloven, \$266b)

I racismeparagraffen angives således en række begrænsninger på, hvad vi må sige om andre. Et andet eksempel er injurielovgivningen, der forbyder fornærmende omtale af andre (Straffeloven, §267). I mere specifikke sammenhænge er vi yderligere begrænsede på, hvad vi må sige. En forhandler af Mazda-biler er underlagt Markedsføringsloven og må derfor ikke omtale konkurrenternes bilmærker negativt (Markedsføringsloven, §5). En arbejdsgiver må ikke tiltale en medarbejder seksuelt (seksuel chikane). En redaktør på et journalistisk medie kan blive pålagt at bringe et genmæle, der modsiger mediets oprindelige ytringer (Medieansvarsloven, kap. 6).

Ytringsfriheden er således allerede begrænset på en række måder. Den Europæiske Menneskerettighedskonvention (EMK) definerer ytringsfriheden forholdsvist præcist. Ytringsfriheden er her defineret som en frihed til at "give eller modtage meddelelser eller tanker, uden indblanding fra offentlig myndighed" (min fremhævelse). Ifølge EMK kan ytringsfriheden kun begrænses, hvis mindst tre betingelser er opfyldt:

1. Begrænsningerne skal være "foreskrevet ved lov"

2. De skal være "nødvendige i et demokratisk samfund ..."

3. "... af hensyn til den nationale sikkerhed" (Lorenzen 2003, art. 10)

Ytringsfriheden er her defineret som en regulering af, hvilke forhold offentlige myndigheder må underlægge sig for at begrænse borgerens ret til at ytre sig. Offentlige myndigheder kan kun begrænse borgerens ønsker om at ytre sig, hvis det er foreskrevet ved lov, og det kan godtgøres, at en begrænsning er nødvendig for at fastholde en sammenhængende, demokratisk, national konstitution.

En ting er naturligvis den lovmæssige sikring af, at man rent faktisk har lov til at ytre sig. En anden ting er mulighederne for, 
at ytringer bliver hørt. Her skelner man i juraen mellem formel, materiel og reel ytringsfrihed (Jørgensen 2011, s. 18-19). Den formelle ytringsfrihed handler om friheden fra forudgående censur, den materielle ytringsfrihed handler om friheden fra efterfølgende retsforfølgelse, og den reelle ytringsfrihed handler om muligheden for at blive hørt og forstået. Fokus for denne artikel er den reelle ytringsfrihed ud fra en pointe om, at den formelle og materielle ytringsfrihed ikke giver nogen mening, hvis ikke der findes en reel mulighed for at udøve sin ytringsfrihed.

For at vende tilbage til EMK's definition kan man altså sige, at det er forfejlet at henvise til ytringsfriheden, når man vil kritisere Apple for at nægte at publicere en applikation, der bl.a. kan vise de letpåklædte piger på side 9 i Ekstra Bladet (se f.eks. Sølvsteen 2010; Kjær 2010). Apple er ikke en offentlig myndighed og er således i sin gode ret til selv at definere, hvilke budskaber man ønsker at formidle. Ligesom de privatejede aviser altid har haft en ret til at sortere i, hvilke artikler, læserbreve, indlæg o.l. man ønsker at bringe - med en simpel henvisning til, at man ikke bryder sig om budskabet. Det kan naturligvis være meget irriterende for den, der ikke bliver hørt. Men et brud på ytringsfriheden er det ikke. Ytringsfriheden beskytter i sin nuværende form kun imod indgreb fra offentlige myndigheder - noget, vi vil vende tilbage til nedenfor.

Ytringsfriheden er med andre ord begrænset på en række områder. Så snart man har erkendt det, bør det også være selvindlysende, at man naturligvis kan diskutere ytringsfriheden. Er ytringsfriheden, som vi kender den, en god ting? Er de nuværende begrænsninger af ytringsfriheden de bedst tænkelige? Hvad kunne mulige grunde til at begrænse ytringsfriheden yderligere være? Kunne der være gode grunde til at udvide ytringsfriheden?

Kun for så vidt vi tør stille disse spørgsmål, og vi kan give overbevisende svar på dem, har ytringsfriheden en eksistensberettigelse. Hvis vi er bange for at diskutere værdien af ytringsfriheden, fordi vi så risikerer at miste den, er det måske, fordi der slet ikke findes gode grunde til at have den? Men for at komme i gang med diskussionen kan det måske være en god ide at (gen)overveje, hvorfor den er så vigtig? 


\section{Ytringsfriheden i Oplysningstiden}

Selv om der findes enkelte ideer om ytringsfriheden langt tilbage i historien, er ytringsfriheden i høj grad et barn af Oplysningstiden. I det 17. og 18. århundrede fortættedes den filosofiske scene således med værker, der på forskellig vis forsvarede ytringsfriheden. Filosoffer som Spinoza, Locke, Hume, Diderot, Voltaire og Kant, digteren Milton og politikere som Jefferson og Madison forsvarede på forskellig vis (mere eller mindre eksplicit) ytringsfriheden, hvilket gav sig det nok mest konkrete politiske udtryk i den første tilføjelse til den amerikanske forfatning fra 1789 .

Begrundelserne for ytringsfriheden varierede naturligvis. Ofte blev de knyttet sammen med ideer om menneskelig frihed og udvikling (f.eks. i Kant 1784). Andre gange var ytringsfriheden kædet sammen med en analyse af, hvordan man bedst sikrede sig imod en voldelig regeringsførelse (f.eks. hos Spinoza 1670, kap. 20). Andre gange igen var overvejelserne knyttet sammen med en refleksion på, hvordan forskellige religioner kunne sameksistere fredeligt (Locke 1689). Ofte var overvejelserne også snævert knyttede til en bekymring for sandhedens fremme (f.eks. i Milton 1643).

Grundlæggende udsprang Oplysningstidens interesse for ytringsfriheden af opgøret med religiøse dogmer. Dermed ikke sagt at ytringsfriheden altid artikuleredes i et opgør med religiøsiteten. Nogle gange (f.eks. i Milton 1643 og Locke 1689) artikuleredes den tværtimod med en henvisning til religiøse tekster. Milton henviser f.eks. til Johannes-evangeliet, kap. 8,32 ("sandheden skal gøre jer frie”) som et argument for at fremme ytringsfriheden.

Snarere kan man sige, at ytringsfriheden skriver sig ind i Oplysningstidens opgør med absolutte autoriteter. Den gradvise vending fra religionen mod fornuften var et udtryk for, at der ikke fandtes én endelig og ufejlbarlig tilgang til verden (det mest paradigmatiske udtryk for denne vending findes i Kant 1781). Derfor var det vigtigt vedholdende at holde alle spørgsmål åbne. Vores forskellige bud på verden og på, hvordan vi indretter os i den, bør hele tiden potentielt være åbne for at kunne betvivles - for et synspunkt har kun gyldighed, for så vidt det kan stå for en rationel 
efterprøvning, og vi kan aldrig være sikre på, at vi har efterprøvet ethvert synspunkt med henblik på enhver mulig udfordring.

Overført til ytringsfriheden er det åbenlyst, at ytringsfriheden kan være besværlig for de siddende magthavere, men set i et demokratisk perspektiv er det netop pointen. De siddende magthavere har i udgangspunktet serveretten for, hvordan vi skal indrette os i samfundet. I et ikke-demokratisk samfund er magthaverne i udgangspunktet ikke nødt til at begrunde de forskellige regler og forordninger. For så vidt magthaverne kan sætte lovgivningen igennem på baggrund af en militær- eller politibaseret fysisk backing, kan man vælge at ignorere borgernes syn på lovgivningen. Det vil ganske vist være nemmere for de fleste magthavere, hvis man kan overbevise befolkningen om lovgivningens fortræffeligheder, men det er ikke strengt nødvendigt i et ikkedemokratisk samfund.

Anderledes stiller det sig med demokratiet. Her kan man argumentere for, at ytringsfriheden garanterer, at ethvert udspil til en samfundsmæssig indretning i det mindste potentielt kan blive mødt med alle mulige indvendinger. For så vidt man ønsker at bevare magten, vil magthaverne derfor være nødt til at kunne besvare en hvilken som helst indvending. Det er ikke det samme som at kunne garantere, at alle bliver tilfredse - det ville nok være for naivt - men man skal som minimum kunne forklare, hvad der retfærdiggør, at man i konkrete tilfælde tilgodeser nogle dele af befolkningen på bekostning af andre. For at være lidt mere konkret: Hvis man f.eks. ønsker at indføre skattelettelser i Danmark ved at skære ned på visse velfærdsydelser, er man nødt til at kunne argumentere for, at det på den lange bane er bedre for Danmark som helhed - og at det derfor også i den sidste ende er bedre for dem, der konkret mister nogle velfærdsydelser.

Demokratisk baseret magtudøvelse er med andre ord baseret på en vedvarende, rationel legitimeringsproces, der indfries ved, at magthaverne skal stå til ansvar for enhver mulig indvending, der kan rejses. Netop derfor er ytringsfriheden så påtrængende i forhold til det offentlige felt i Danmark - på en helt anden måde end i forhold til det privatøkonomiske felt. Demokratiet er principielt bygget op på en fornuftsbaseret forståelse af det politiske, hvor de synspunkter og argumenter, der kan stå op imod ytringsfrihedens lavine af mulige indvendinger, vinder. Oplysningstæn- 
kerne havde en ide om, at dette muligvis ikke førte til det perfekte samfund - men dog til det mindst ringe.

Nu skal man naturligvis ikke være blind for, at denne forståelse af demokratiet er meget idealistisk - og givetvis også grænsende til det naive. I realiteten er det nok sjældent, at magthavernes administration af magten reelt udsættes for en tilbundsgående prøvelse i forhold til alle mulige indvendinger. Ligeledes er den enkelte borgers stemmeafgivelse desuden nok også i lige så høj grad styret af personlige sympatier som af en rationel evaluering af den enkelte politikers argumenter og synspunkter. Men dermed ikke være sagt, at de demokratiske idealer er helt uden konkret realitet. Som en reel mulighed er ytringsfriheden en stadig virkelighed, som magthaverne på den ene side må tage alvorligt - for hvis de bliver taget i at regere håbløst, tendentiøst eller magtmisbrugende, er de færdige som magthavere. På den anden side måler borgerne magthaverne på deres evne til at respektere ytringsfriheden - hvis borgerne får indtryk af, at magthaverne undgår at stille op til kritisk udveksling (f.eks. i medierne), mister de deres troværdighed.

\section{Ytringsfrihed på det privatøkonomiske felt}

Den begrænsede ytringsfrihed giver altså god mening på det politiske felt. Men lidt anderledes stiller det sig på det privatøkonomiske felt. Det privatøkonomiske felt er ikke orienteret mod rationel legitimitet i samme forstand. Når vi handler, tænker vi ikke på, om de udvekslede varer lever op til en legitimitet, der kan modstå enhver rationel indvending. En handel baserer sig på, om de udvekslede varer giver en behovstilfredsstillelse, der er passende i forhold til den ydelse, vi selv skal sende den anden vej. Og markedslogikken er så bygget op på den måde, at hvis forholdet mellem vare og pris ikke er tilfredsstillende, så finder vi en anden udbyder. ${ }^{1}$

Derfor har den enkelte private agent på det økonomiske felt heller ingen forpligtelse til at tage højde for alle potentielle indvendinger imod vedkommendes produkter. Hvis forbrugerne er utilfredse, kan de vælge en anden udbyder. Den enkelte udbyder har naturligvis en egoistisk interesse $\mathrm{i}$, at flest muligt faktisk vælger udbyderens produkter, men hvis man ikke opfylder bruger- 
nes ønsker, er det i udgangspunktet ens eget problem. Ytringsfriheden er således ikke nødvendigvis knyttet til en markedslogisk, økonomisk udveksling.

Så når Apple f.eks. nægter at hoste en applikation, der kan bruges til at formidle Ekstra Bladets letpåklædte piger, begrænser refleksionen sig til, at Apple vurderer, hvordan det vil påvirke virksomhedens fremtidige evne til at tiltrække ny omsætning. Her vurderede man så i første omgang, at man ville miste mere omsætning, end man ville vinde. I foråret 2011 skønnede man tilsyneladende, at den første vurdering var forkert, og derfor åbnede man alligevel for at hoste applikationen. Man kan sige, at forløbet ikke var særligt elegant, men det var ikke i nærheden af at være et brud på ytringsfriheden, som vi kender den. Apple har ingen pligt til at give rum for offentlige stemmer, man ikke bryder sig om. Hvis man kunne tvinge de forskellige private agenter i offentligheden til at bringe alle tænkelige budskaber, ville det umuliggøre en markedsorienteret fokusering i retning af forskellige segmenter på markedet.

Når det er sagt, har der i Danmark været en tradition for, at en række private nyhedsformidlere i første omgang har underlagt sig selv en række publicistiske forpligtelser, og siden 1992 har de været underlagt en decideret presseetisk lovgivning, der forpligter dem ud over rent markedslogiske præmisser (Andersen 2006). Det skete med udgangspunkt i en massemedial situation, hvor man kan argumentere for, at disse medier havde en uomgængelig placering i den danske offentlighed. Hvis man ville orientere sig i det danske landskab, var massemedierne eneste indgangsport til information, og derfor kunne man ud fra en demokratisk tankegang argumentere for, at det offentlige havde en forpligtelse til at sikre, at det massemedierede billede var troværdigt. ${ }^{2}$ Men igen er det værd at lægge mærke til, at det presseetiske regelsæt ikke forpligter de omhandlede medier indholdsmæssigt. Regelsættet regulerer ikke, hvilke emner der skal tages op, men snarere hvordan man behandler de emner, der tages op.

\section{Brydninger mellem de økonomiske og politiske felter}

Så længe der er en klar adskillelse mellem de politiske og økonomiske felter, giver den nuværende opdeling og udformning af 
ytringsfriheden forholdsvist god mening. Spørgsmålet er imidlertid, om adskillelsen til stadighed kan opretholdes? Grundloven og Den Europæiske Menneskerettighedskonvention er artikuleret med nationalstaten for øje. Nationalstaten er kendetegnet ved en klar jurisdiktion (den geografiske udstrækning) og en klart defineret befolkning (borgerne). Lovgivningen sætter forholdsvist klare rammer for, hvad man må i hvilke situationer - og hvis man ikke respekterer lovgivningen, kan man blive retsforfulgt og stillet til ansvar.

Spørgsmålet er imidlertid, om den nationalstatslige forståelse af det juridiske og politiske kan opretholdes? Den traditionelle opfattelse af det politiske som snævert bundet til nationalstaten er nemlig under udfordring på forskellige måder. I de senere år har flere analytikere peget på, at nationalstaten er under pres (Hardt \& Negri 2000; Benkler 2006; Lessig 2006). Det er der mange grunde til, men i nærværende sammenhæng er den mest interessante faktor nok fremkomsten af nye kommunikative medier - medier, der på forskellig vis understøtter kommunikation på tværs af jurisdiktioner og folk.

Den nationale indlejring af politikken er derfor udfordret. Dels fordi (a) de enkelte landes jurisdiktioner efterhånden begynder at række ud efter borgere i andre lande; dels fordi (b) globale aktører (dvs. aktører, der ikke er entydigt rodfæstet til bestemte nationer) i stigende grad eroderer muligheden for at opretholde grænser for ytringsfrihed; dels fordi (c) globale kommercielle aktører i stigende grad har herredømmet over, hvilke dagsordener der får en fremtrædende plads i offentligheden.

\section{(a) Lovgivning på tværs af grænserne}

Her er internettet naturligvis en særligt stærk facilitator. Internettet er struktureret på en måde, der kun i meget ringe grad faciliterer en national forståelseshorisont. Ud over DNS-protokollens landekode er de væsentligste af internettets protokoller kendetegnet ved en indifferens over for nationale grænser. På indholdssiden begrænses kommunikationen ganske vist stadig af sproglige begrænsninger og af, at brugerne stadig fysisk set er indfældet i en række lokale og nationale interessefællesskaber. Derfor foregår langt den overvejende del af internetkommunikationen stadig inden for nationale horisonter. ${ }^{3}$ 
Det ændrer imidlertid ikke ved, at internettet muliggør, at man kan ytre sig på måder, som er lovlige der, hvor man fysisk befinder sig, men samtidig er ulovlige hos potentielle modtagere. Så hvis f.eks. amerikanske Yahoo! hoster en auktion med nazistisk udstyr, som kan tilgås af franske borgere, kan selskabet dømmes efter fransk lovgivning til at fjerne det - også selv om serveren med auktionen konkret står et helt andet sted i verden (eksemplet er taget fra Lessig 2006, s. 294-5). Eller hvis en canadisk hjemmeside streamer tv fra USA, hvilket er lovligt ifølge den canadiske lovgivning, er man ifølge USA's lovgivning forpligtet til at forhindre, at indholdet kan modtages af USA's borgere (Lessig 2006, s. 295-6).

\section{(b) Erodering af begrænsningerne på ytringsfriheden}

Noget helt andet er naturligvis så, hvordan mulighederne er for at retsforfølge lovbrydere, der placerer sig uden for de brudte loves jurisdiktion. I de ovenfor nævnte sager lykkedes det de nationale domstole at få lukket ned for indholdet. I nyere tid har bl.a. sagerne med WikiLeaks imidlertid vist, at det ikke altid er så ligetil. Hjemmesiden WikiLeaks fik i Danmark første gang offentlig bevågenhed, da man 16. september 2009 sammen med Politiken og hjemmesiden The Pirate Bay offentliggjorde Thomas Rathsacks bog Joeger - $i$ krig med eliten uden om de officielle danske rettighedshavere. Efterfølgende har den fået stor international bevågenhed, da man i efteråret 2010 ad flere omgange offentliggjorde amerikanske diplomatiske og militære dokumenter.

WikiLeaks har som erklæret mål at modarbejde lovmæssige begrænsninger af ytringsfriheden:

"WikiLeaks has sustained and triumphed against legal and political attacks designed to silence our publishing organisation, our journalists and our anonymous sources." (anonymous 2011)

Det, der sikrer organisationer som WikiLeaks overhånden $\mathrm{i}$ disse situationer, er, at man kan placere sine servere i lande med den mest vidtgående beskyttelse af ytringsfriheden og så sprede informationer til lande med mere restriktiv ytringsfrihed.

Denne situation underminerer effektiviteten af at artikulere grænser for ytringsfriheden. Det er ikke det samme som at sige, 
at vi får en absolut ytringsfrihed (jf. overvejelserne i begyndelsen af denne artikel). Men det betyder, at de faktiske grænser for ytringsfriheden er ude af de nationale myndigheders hænder. Og hermed er vi fremme ved det tredje pres på den nationale politik.

\section{(c) Globale aktører sætter grænserne for ytringsfrihed}

For ligesom de nationale myndigheders evne til at begrænse ytringsfriheden undermineres, er mulighederne for at sikre en fair og repræsentativ gengivelse af de offentligt relevante problematikker ${ }^{4}$ også i tiltagende grad ude af de nationale myndigheders hænder. En refleksion over Googles placering i dannelsen af offentlighedsfeltet kan demonstrere dette:

Når vi skal opsøge nye informationer på internettet, går de fleste brugere ind omkring Googles søgemaskine. Den er hurtig, effektiv og har en imponerende evne til at finde de mest relevante links. Søgemaskinen ejes af det private firma Google Inc, og som sådan er den i princippet ikke underlagt lovgivningen om ytringsfrihed. Google kunne f.eks. godt vælge at sige, at man ikke ville bringe links til Ekstra Bladets letpåklædte kvinder. Man ville muligvis miste nogle kunder, men på den anden side ville mange forældre måske være mere villige til at lade deres børn bruge Googles søgemaskine.

Så langt er det måske forholdsvist ukontroversielt. Men i den kinesiske udgave af Googles søgemaskine gik man i 2006-2010 meget længere end som så, idet man efterkom de kinesiske myndigheders ønske om at bortfiltrere politiske budskaber om bl.a. menneskerettigheder. Her var det ganske vist efter et ønske fra myndighedernes side og i forholdsvist fuld offentlighed. Derfor udfordrer dette eksempel ikke i sig selv den nationale forståelse af det politiske: Kinesiske myndigheder har en meget restriktiv opfattelse af, hvor de frugtbare grænser for ytringsfriheden går, og dem måtte Google efterkomme, hvis man ville være en del af den kinesiske offentlighed. ${ }^{5}$

Det interessante er imidlertid, at når de kinesiske myndigheder kunne se en interesse i få oprettet en myndighedsvenlig udgave af Google, så siger det noget om Googles fremtrædende placering i dannelsen af den offentlige opinion. Og eksemplet viser, at Google kun følger sådanne henstillinger, så længe man finder det passende i forhold til virksomhedens generelle place- 
ring på markedet.

Men er der offentlighed omkring, hvordan Google sorterer de informationer, som man leverer til offentligheden? Google filtrerer og sorterer sine data efter en række kriterier. Her er Google i en stadig kamp mod andre kommercielle aktører for at sikre brugerne de resultater, som de finder relevante. Som udbydere af en vare er rigtigt mange kommercielle aktører interesserede $\mathrm{i}$, at deres produkter skal ligge højt i en Google-søgning. Derfor forsøger de at optimere deres hjemmesider, så flest mulige brugere kigger forbi - nogle gange på bekostning af at brugerne må gennem en del links, inden de finder det, de faktisk søgte. Derfor er Google grundlæggende set nødt til at forsøge at holde sine sorteringskriterier hemmelige - i et forsøg på at forhindre kommercielle aktører i at udnytte dem uhensigtsmæssigt.

Det er imidlertid også klart, at sorteringsmekanismer altid vil favorisere nogle på bekostning af andre. I takt med Googles fremtrædende placering i vores brug af internettet får Googles sorteringskriterier en stigende betydning for, hvilke budskaber der bliver hørt. Jeg er ikke ude på at antyde, at Google generelt skulle have en bevidst filtrering, der forhindrer bestemte emner i at blive diskuteret. Men man kan ikke udelukke muligheden af, at nogle af Googles sorteringsmekanismer reelt set betyder, at visse emner har sværere ved at blive en del af den politiske offentlighed. Og at Google dermed er med til at forme visse grænser for ytringsfriheden.

Det er naturligvis ikke nyt, at store spillere i den offentlige sfære har stor indflydelse på, hvilke emner der kan opnå offentlig bevågenhed. Det nye er imidlertid, at de store spillere er globale i deres karakter. Ved de traditionelle papir- og æterbårne massemedier var det muligt at indføre nationalt definerede presseetiske regler, der kunne regulere de store aktørers udbredelse. Kinaeksemplet viser, at noget tilsvarende kan lade sig gøre i forhold til de store globale aktører også. Men det kræver for det første en meget stor teknologisk indsats, og for det andet kræver det nok også en politisk volumen af en vis størrelse, hvis man vil afkræve en aktør som Google så grundlæggende indgreb i virksomhedens interessesfære. 


\section{Ytringsfriheden i den kosmopolitiske verdensorden}

De tværnationale kommunikative medier medfører med andre ord, at den nationale forståelseshorisont for ytringsfriheden er under pres. Michael Hardt og Antonio Negri har argumenteret for, at vi ikke nødvendigvis skal begræde, at den nationale horisont for det politiske står for fald. Nationalstaten har på mange måder rummet en meget repressiv kraft (Hardt \& Negri 2000, s. 43; se også Hardt \& Negri 2004 og 2009).

Problemet er imidlertid, at det er uklart, hvem eventuelle nye magtcentre skal og bør stå til regnskab for - og hvilke regler, normer og værdier der kan og bør forpligte disse aktører? Artikel 19 i FN's Verdenserklæring for Menneskerettigheder er naturligvis et oplagt sted at kigge efter en forpligtende artikulering af ytringsfriheden på tværs af landegrænserne. Problemet med FN er imidlertid, at denne institution netop er international og ikke transnational. FN har derfor kun autoritet, for så vidt medlemslandene har det, og for så vidt de kan blive enige.

Magt er defineret ved at hæfte sig ved sociale agenter. Den flyder aldrig subjektfrit, men udøves altid mellem sociale agenter. Hvis nogle agenter (f.eks. de politiske nationer) bliver mindre oplagte som magtudøvere, styrkes andre aktørers magtbehændighed. Ifølge Hardt og Negri har nationernes fald medført, at politikken tænkes mere økonomisk. Spørgsmålet er så, om man kan tænke sig, at de traditionelle demokratiske kernepiller (så som ytringsfriheden) kan oversættes i økonomisk logiske termer?

Man kunne hævde, at opstanden omkring Apples fravalg af Ekstra Bladet kunne bekræfte en sådan tanke. Apple har tydeligvis konkluderet, at fravalget har skadet virksomhedens omdømme, og derfor har man valgt at give plads til alle Ekstra Bladets budskaber. Ytringsfriheden er således blevet beskyttet gennem en markedslogisk kalkule. Spørgsmålet er imidlertid, om markedslogikken grundlæggende spiller til fordel for åbenhed og ytringsfrihed, og her må man nok konkludere, at eksemplerne i afsnit VI ovenfor peger i lidt forskellige retninger.

Sagen er, at vi har brug for en begraenset ytringsfrihed - en ytringsfrihed, der er klart defineret ved, at nogle typer af ytringer altid bør kunne finde vej til offentligheden; nogle typer af ytringer er lidt lige meget; og endelig må vi også afklare, om der fin- 
des nogle ytringer, der aldrig bør kunne komme ustraffet ind i offentligheden? Ved at lade markedslogikken råde, bliver ytringsfriheden en tilfældighed, som afhænger af, om folk kan hidse sig tilstrækkeligt op til at kæmpe for en konkret sag. En tilfældig ytringsfrihed kan man ikke regne med, og derfor giver det ikke mening at tænke den som en rettighed. Eller for at vende tilbage til Agambens pointe: Hvis ikke ytringsfriheden har et klart udenfor - en klar eksklusion - så forsvinder den enten fra vores forståelseshorisont, eller den ender med at tyrannisere os.

Det største problem i dag (i takt med at nationerne mister deres gennemslagskraft) er derfor, at "vi” i en vis forstand - vi forstået som nationalstatens borgere - ikke kan begrænse ytringsfriheden, og derfor ender vi måske med at miste den. Derfor er det nu, vi skal begynde at diskutere ytringsfriheden - hvilken rolle skal ytringsfriheden spille i fremtidens krydsfelt mellem økonomisk markedslogik og politisk regulering? Vi skal til at diskutere, hvordan vi vil begrænse den. Hvis ikke vi kender vores besøgelsestid, bliver det for sent.

Udfordringen er imidlertid, at hvis nationalstaten mister sin status som horisont for det "vi”, der skal diskutere, hvilken horisont står så til rådighed for os? Jeg har i anden sammenhæng (Hansen 2011) diskuteret, hvorledes der på internettet er opstået nogle fællesskaber, der i samspil med en nyartikulering af markedslogiske spilleregler har formuleret en radikal åbenhedspolitik, der på mange måder er drevet af nogle af de samme logikker, som i Oplysningstiden var drivkraften for artikuleringen af ytringsfriheden. Jeg tænker her på open source-bevægelsen (se f.eks. Ockman et al. 1999). Open source-bevægelsen er kendetegnet ved en tankegang, hvor man tilskriver information en "ret" til at være åbent tilgængelig. Pointen er, at en sådan tankegang kræver en nytænkning af, hvad det vil sige som aktør i organisationen at være skaber og ejer af noget. En information, der er åbent tilgængelig, kan man ikke eje eksklusivt i samme forstand, som når man ejer en ting. Dette udfordrer det økonomiske udvekslingsforhold, idet den økonomiske gevinst ikke kan skabes gennem en eksklusiv viden, men derimod gennem agentens evne til at operationalisere den pågældende viden.

At oversætte open source-tankerne til en nyartikuleret ytringsfrihed vil givetvis kræve en omfattende refleksion. Pointen i 
denne sammenhæng er imidlertid, at open source-bevægelserne allerede har gjort sig en række erfaringer med at gå fra det ideologiske til det økonomiske felt. Open source-tankerne er født ud af en bestræbelse på at forene åbenhed med økonomisk rentabilitet, hvorimod Oplysningstidens ideer om ytringsfriheden er født ind i en forståelse af det politiske som noget, der skal tøjle det økonomiske. I takt med at den traditionelle forståelse af politik som et alternativ til det økonomiske felt således nedbrydes, kunne det være oplagt at vende sig til en forståelse af politik og organisation, der er født ind i det økonomiske felt.

Pointen er, at på det økonomiske felt finder vi kimen til transnationale institutioner (f.eks. Verdenshandelsorganisationen WTO), der er født til at regulere varernes bevægelighed mellem grænserne. En diskussion og nyartikulering af det økonomiske udvekslingsforhold baseret på en open source-inspireret tankegang har derfor allerede et sted, hvor den kunne foregå og befæstes.

Hvis man vil. Det vil man foreløbig nok ikke, men spørgsmålet er, om vi på den lange bane kan blive fri - hvis vi vil bevare en begrænset ytringsfrihed?

Det ville føre for vidt på dette sted at give en uddybet gennemgang af dette konkrete bud på en nyartikulering af spillereglerne for ytringsfrihed. Min pointe er primært, at diskussionen $b ø r$ finde sted, og at den rent faktisk allerede finder sted. Hvis vi vil have en indflydelse på, hvilken retning diskussionen skal tage, er det på tide, at vi kaster os ud i den og ikke gemmer hovedet i busken, af frygt for at ytringsfriheden skal gå i stykker, hvis vi rører ved den.

EJVIND HANSEN, Forskningschef i journalistisk filosofi, Danmarks Medie- og Journalisthøjskole, eh@dmjx.dk

\section{LITERATURLISTE}

- (1993): Danmarks Riges Grundlov af 5. juni 1953 og Tronfølgerlov af 27. marts 1953, København.

- (2010): Straffeloven; Lov om fuldbyrdelse af straf m.v., 42. ed., Valby: Schulz Information. 
Agamben, Giorgio (1998): Homo sacer: sovereign power and bare life, Stanford, Calif.: Stanford University Press.

Andersen, Michael Bruun (2006): "Fra presseetik til markedsmoral”, Journalistica - Tidsskrift for forskning i journalistik, (Journalistikkens roller), , nr. 1, s. 25-41.

Anonymous (2011): “About: What is Wikileaks”, retrieved on 01.06.2011 from http://wikileaks.org/About.html.

Benkler, Yochai (2006): The wealth of networks: how social production transforms markets and freedom, New Haven Conn.: Yale University Press.

Clemmensen, Lillan (2010): "Skarp kritik af Politikens undskyldning", Information.dk, København, 26th February.

Derrida, Jacques (1996): Apories : mourir, s'attendre aux "limites de la vérité," Paris: Galilée.

Derrida, Jacques (1994): Force de loi : le "Fondement mystique de l'autorité," Paris: Galilée.

FDIM (2011): Danskernes brug af internettet - 2011, København: Foreningen af Danske Interaktive Medier.

Hansen, Ejvind (2011): “Den åbne kapitalisme”, i Hansen, Ejvind; Thorup, Mikkel; Raffnsøe-Møller, Morten (red.), Kapitalismernes ansigter, Aarhus: Philosophia.

Hardt, Michael; Negri, Antonio (2009): Commonwealth, Cambridge Mass.: Belknap Press of Harvard University Press.

Hardt, Michael; Negri, Antonio (2000): Empire, Cambridge Mass.: Harvard University Press.

Hardt, Michael; Negri, Antonio (2004): Multitude : war and democracy in the age of Empire, New York: The Penguin Press.

Juhl, Jeppe (2010): "Islam og de andre religioner er fritaget for saglig kri$t i k$ ", 180grader, retrieved on 26.05.2011 from http://www.180grader. $\mathrm{dk} /$ Politik/islam-og-de-andre-religioner-er-fritaget-for-saglig-kritik.

Jørgensen, Oluf (2011): Mediejura - det handler om informations- og ytringsfrihed, Aarhus: Forlaget Ajour.

Kant, Immanuel (1784): “Beantwortung der Frage: Was ist Aufklärung?”, i Akademieausgabe von Immanuel Kants Gesammelten Werken: Band VIII: Abhandlungen nach 1781, Berlin: Felix Meiner Verlag, s. 33-42.

Kant, Immanuel (1781): Kritik der reinen Vernunft, Hamburg: Felix Meiner (1990).

Kjær, Jakob Sorgenfri (2010): “Apple presser avisernes ytringsfrihed”, Politiken, 1st November. 
Lessig, Lawrence (2006): Code : version 2.0, New York, N.Y.: Basic Books. Locke, John (1689): “An Essay concerning Toleration”, i Milton, J.R. (red.), John Locke: An Essay concerning Toleration: And Other Writings on Law and Politics, 1667-1683, Oxford: Oxford University Press.

Lorenzen, Peer (2003): Den Europoiske Menneskerettighedskonvention, med kommentarer, København: Jurist- og Økonomforbundets Forlag. Milton, John (1643): “Areopagitica”, i Alvis, John (red.), Areopagitica, and other political writings of John Milton, Indianapolis: Liberty Fund.

Ockman, Sam; Stone, Mark; DiBona, Chris (1999): Open sources : voices from the open source revolution, Beijing: O'Reilly.

Spinoza, Benedictus de (1670): Theological-political treatise.

Surrugue, Stéphanie; Tuxen, Johanne Pontoppidan (2005): "Profetens ansigt: »Vi skal opføre os ordentligt «”, Politiken, 27th October.

Sølvsteen, Claus (2010): "Apple angriber ytringsfriheden", Computerworld, retrieved on 27.05.2011 from http://www.computerworld.dk/ art/112443/apple-angriber-ytringsfriheden.

TV2 Nyhederne (2005): “Fogh: Muslimer må gå til domstole”, retrieved on 26.05.2011 from http://nyhederne-dyn.tv2.dk/article.php/id3057974:fogh-muslimer-m\%C3\%A5-g\%C3\%A5-til-domstole.html.

Vangkilde, Jesper (2011): "Per Stig Møller: Sass-forslag er »meget, meget uhyggeligt «”, Politiken.dk, 26th May.

1 Jeg ser her bort fra situationer, hvor en udbyder har monopol på markedet.

2 At den formelle og materielle ytringsfrihed med andre ord ikke havde megen relevans, hvis man ikke sikrede, at der var en offentlighed, hvor ytringer kunne få en reel indflydelse på den samfundsmæssige dagsorden.

3 Hvis man filtrerer trafikken fra Google og Facebook fra, går langt den overvejende del af danskernes internetforbrug til danske sites (FDIM 2011, s. 13-18).

4 Dvs. den reelle ytringsfrihed - jf. den juridiske distinktion tidligere i artiklen.

5 Da Google i 2010 erklærede, at man ikke længere ville yde den ønskede filtrering af resultaterne, lukkede de kinesiske myndigheder for, at kineserne kan tilgå Googles sider. 